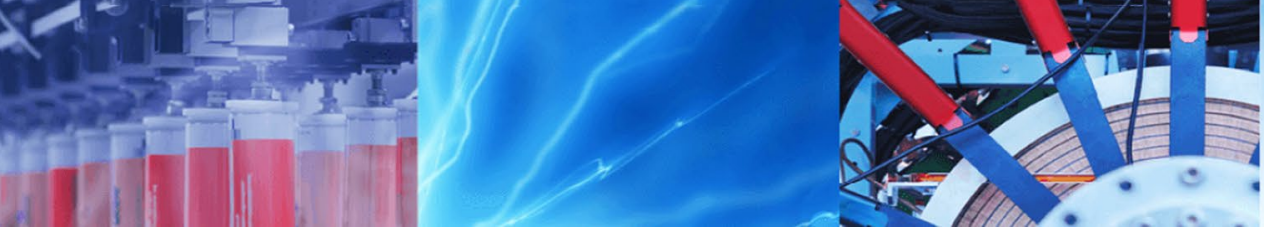

Review Paper

\title{
Threat of arsenic contamination, salinity and water pollution in agricultural practices of Sundarban Delta, India, and mitigation strategies
}

\author{
Anirban Nath ${ }^{1}$ D $\cdot$ Sourav Samanta ${ }^{2}$ Saon Banerjee ${ }^{3} \cdot$ Anamitra Anurag Danda $^{4} \cdot$ Sugata Hazra $^{2}$ (D)
}

Received: 24 September 2020 / Accepted: 31 March 2021

Published online: 15 April 2021

(C) The Author(s) 2021 OPEN

\begin{abstract}
The paper through a critical appraisal of the agricultural practices in the Indian Sundarban deltaic region explores the tripartite problems of arsenic biomagnification, salinity of arable lands and ingress of agrochemical pollutants into the freshwater resources, which endanger the health, livelihood and food security of the rural population inhabiting the delta. The threefold problem has rendered a severe blow to the agrarian economy consequently triggering large-scale outmigration of the rural population from the region. Although recent studies have addressed these issues separately, the inter-connectivity among these elements and their possible long-term impact upon sustainability in the Sundarbans are yet to be elucidated. In the current scenario, the study emphasizes that the depleting freshwater resources is at the heart of the threefold problems affecting the Sundarbans. Owing to the heavy siltation of the local river systems, freshwater resources from the local ravines have salinized beyond the point of being used for agricultural purposes. At the same time, increasing salinity levels resulting from fluctuation of pre- and post-monsoon rainfall, frequent cyclones and capillary movement of salinized groundwater (primarily during the Rabi season) have severely hampered the agricultural practices. Salinization of above groundwater reserves has forced the farmers toward utilization of groundwater, which are lifted using STWs, especially for rice and other cultivations in the Rabi season. The Holocene aquifers of the region retain toxic levels of arsenic which are lifted during the irrigation process and are deposited on to the agricultural fields, resulting in bioaccumulation of As in the food products resourced from the area. The compound effect of consuming arsenic-contaminated food and drinking water has resulted in severe health issues recorded among the local population in the delta. Furthermore, due to the sub-optimal conditions for sustaining agriculture under saline stress, farmers often opt for the cultivation of post-green revolution high-yielding varieties, which require additional inputs of nitrogen-based fertilizers, organophosphate herbicides and pesticides that are frequently washed away by runoff from the watershed into the low-lying catchment areas of the biosphere reserve. Such practices have endangered the vulnerable conditions of local flora and fauna. In the present situation, the study proposes mitigation strategies which necessitate the smart use of locally obtainable resources like water, adaptable cultivars and sustainable agronomic practices like organic farming. The study also suggests engaging of conventional plant breeding strategies such as "Evolutionary plant breeding" for obtaining cultivars adapted to the shifting ecological conditions of the delta in the long run.
\end{abstract}

Keywords Arsenic $\cdot$ Salinity $\cdot$ Rice $\cdot$ Evolutionary plant breeding $\cdot$ Sundarbans

$\triangle$ Anirban Nath, anirbannathkol@gmail.com | ${ }^{1}$ Department of Genetics and Plant Breeding, Institute of Agricultural Science, University of Calcutta, 51/2, Hazra Road, Kolkata 700019, India. ${ }^{2}$ School of Oceanographic Studies, Jadavpur University, Jadavpur, Kolkata,

West Bengal 700032, India. ${ }^{3}$ Faculty of Agriculture, Agricultural Meteorology and Physics, Bidhan Chandra Krishi Viswavidyalaya, P.O. Krishi Viswavidyalaya, Mohanpur, Dist-Nadia, West Bengal 741252, India. ${ }^{4}$ Observer Research Foundation, New Delhi, India. 


\section{Introduction}

The Indian Sundarban Delta (ISD) is a part of the lower deltaic plain of the Ganga being drained by the Ganga and its distributaries. The tide-dominated delta spans over $6406 \mathrm{~km}^{2}$ over 19 administrative blocks $\left(213230^{\circ} \mathrm{N}\right.$ to 22 $3800^{\circ} \mathrm{N}$ and $880220^{\circ} \mathrm{E}$ to $890540^{\circ} \mathrm{E}$ ) belonging to two administrative districts of West Bengal, India. Agriculture is an essential part of the rural economy in the region and vast numbers of arable lands are essentially used for rice cultivation. Although an extensive share of the population (about 5 million people of the region) has shown a gradual increase over the years, the rice production has not seen a successive growth owing to environmental stressors like salinization of wasteland water resources, land erosion, flood and frequent cyclones. The decline in productivity of the arable lands has resulted in mass-migration of the rural population in the delta for an alternative livelihood [43]. The sustainability of agriculture has been further threatened by arsenic contamination of crops which are irrigated and processed using As-contaminated water from the local Holocene aquifers of the Bengal basin. Furthermore, increased uses of agrochemicals along with natural and anthropogenic factors have led to increased toxicities of freshwaters of the estuaries by agricultural chemicals and heavy metal pollutants. Among the issues mentioned above, salinization, arsenic contamination and water pollution from agrochemicals directly appear to jeopardize the attempt for sustainable agricultural development in the region. The current paper focuses on these three significant subjects pertaining to the achievement of the sustainability in the context of agriculture through possible mitigation strategies that can be adopted to realize them. Such measures can ultimately help to realize sustainable development goals ( 1 and 2 ) in the region.

\section{Area of study}

The area investigated includes a total of 19 administrative blocks belonging to two administrative districts of West Bengal, India, viz. North and South 24 Parganas, comprising the Sundarban Biosphere Reserve (SBR). It hosts the most biologically productive natural ecosystem-the Sundarban Mangrove Forest, a World heritage and a Ramsar Site. The area is predominantly situated in the new alluvial and coastal saline agroclimatic zone of West Bengal, at an altitude of 3-8 $\mathrm{m}$ from sea level. The area comprises of loamy or clay loamy soil with rice, jute and potato as the major crops cultivated in the region along with horticultural fruits and vegetables.

\section{Problems related to freshwater availability and rice cultivation in the ISD}

\subsection{Salinization of freshwater resources}

Scarcity of freshwater, both in the surface and subsurface water reserves is one of the major contributing factors that restraints agriculture and food security in the region. The situation is critical in the administrative blocks, namely Gosaba, Sagardwip, Namkhana, Fresarganj, Kakdwip, Patharpratima, Canning, etc. The freshwater supply to the Sundarbans is primarily governed by the hydrological conditions of the rivers that drain the area [46], 58. Heavy siltation and anthropogenic interventions have resulted in a loss of connections between the Parent Rivers and their distributaries, ultimately leading to the ingress of saline seawater into the local estuaries. Furthermore, the influent discharge of the local rivers has resulted in increased salinization of the groundwater, which is available from the shallow aquifers located in the region [6]. The severe impact of heavy siltation, resulting in waterlogging and increased salinity is quite evident in the Gosaba islands (belonging to the Sundarbans), as recorded in the recent works of Ghosh and Mistri [41]. Additionally, studies conducted by Banerjee [5] and Biswas et al. [12] indicate that the salinization shows wide heterogeneity across the eastern, western and central sectors of the Sundarban, with hyper-salinization in the central sector compared to eastern and western parts. Furthermore, the salinity level also varies with respect to the seasonal variation in monsoon rainfall (i.e., pre-monsoon, monsoon and post-monsoons). The impact of soil salinity is further influenced by heterogeneity of the soil in respect to $\mathrm{pH}$, organic compounds, soil organic carbon, etc. The overall distribution of groundwater salinity across the Indian Sundarban is illustrated in Fig. 1.

In the recent times, investigations conducted by Dasgupta et al. [79] revealed that the water samples from the local rivers viz. Bidya, Matla, Hooghly and Raimangal showed salinity levels significantly high in seven administrative blocks of Sundarbans (Fig. 2). In another study, Chowdhury et al. [24] identified a considerable rise in salinity levels recorded in the tidal waters of Sundarbans under post-AILA situations. The investigation revealed that the increased salinization of the tidal waters has severely impacted the local mangrove biodiversity.

The increased salinization of surface waters can be primarily attributed to the alarming rise of the sea level at an estimated rate of $3.44 \mathrm{~mm} /$ year in the Sundarbans [44], along with recurrent occurrence of tropical cyclones like AILA and AMPHAN, which leads to severe storm surges that further pushes the salt waters inland into the agricultural 
Fig. 1 Sundarban Biosphere reserve showing 19 administrative blocks with arsenic (area depicted in Pink shade) and saline groundwater (area depicted in the Yellow shade), affecting monsoon and postmonsoon crop (in respective ratio) and the subsequent mangrove forest area

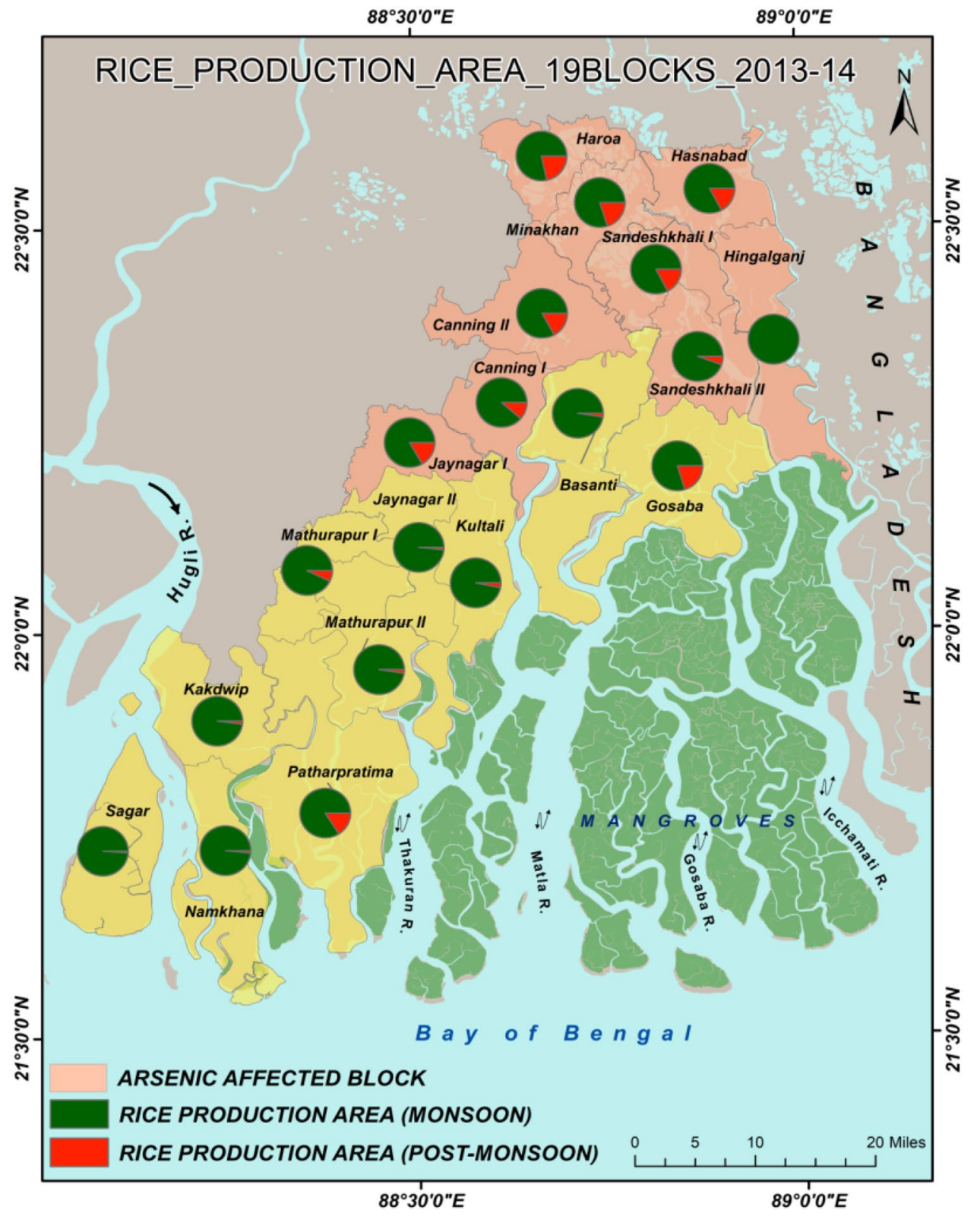

fields, rendering several acres of land unfit and unusable for cultivation.

Furthermore, the vertical transport of salinized surface water into the local shallow aquifers contributes to the escalating of salinization process of the aquifers, which are considered important for ensuring irrigation during the Rabi season. On the basis of the $\mathrm{Cl}$ / $\mathrm{HCO}_{3}$ ratios, calculated for the freshwater extracted from the local shallow aquifers, Bhadra et al. [7] suggested that the intrusion of saline seawater into the freshwater reserves of the shallow aquifers were quite evident. As a result, the water extracted from such aquifers is considered to be inconsumable. The salinization of the groundwater further poses an acute obstacle toward its utilization in agricultural purposes. Vulnerability of the local aquifers was further confirmed by investigations of Rani et al. [66]. Based on the GALDIT index, their study revealed that the aquifers located in the North and South 24 Parganas of the Indian Sundarbans were at highly vulnerable state, with parameters like high hydraulic conductivity, aquifer thickness and saltwater intrusion playing a major role (based on single parameter sensitivity analysis). Furthermore, on the basis of chemical analysis the researchers revealed that high chloride concentrations were detected in the groundwater extracted from aquifers located in the vicinity of Hasnabad, Canning I and II, Sagar, Mathurapur and Kultali blocks of Indian Sundarbans. Such results further confirm the possibility 
Fig. 2 Forty-three locations across seven administrative blocks of Sundarbans showing high river water salinity $>2$ part per thousands (above permissible limit for paddy irrigation), recorded during dry seasons of the year 2019. Numbers within parenthesis indicate location numbers in each administrative block. Source: Dasgupta et al. [79]. https://datacatalog. worldbank.org/dataset/indiawater-tube-well-and-river-salin ity-indian-sundarban
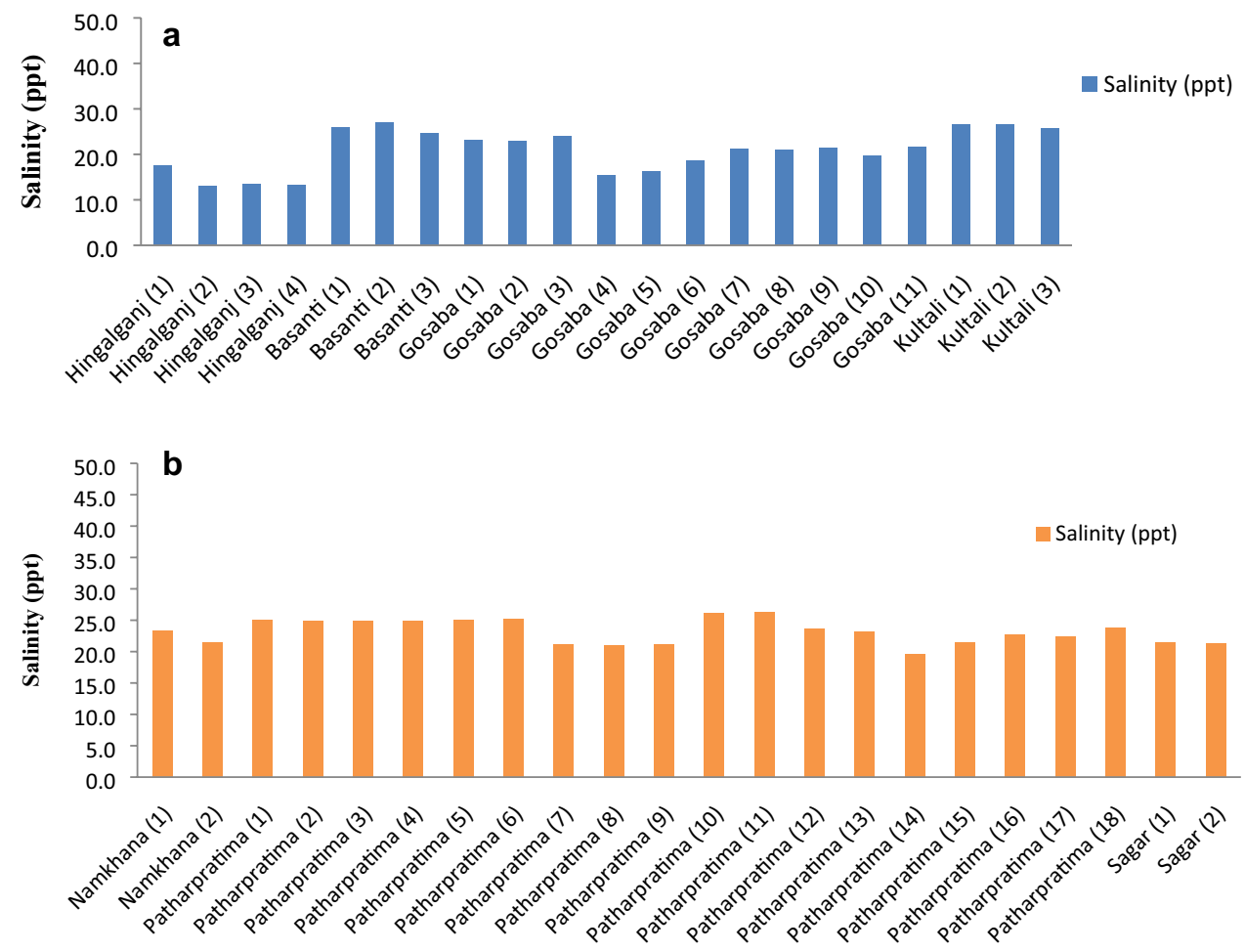

of seawater intrusion into the aquifers situated in the Sundarbans.

The agrarian economy of the region being chiefly dependent upon rice, vulnerability of rice crop toward saline stress further complicates the issue for the rural population [17].

Under salt stress, enhancing or even sustaining of rice production in the area can be quite challenging. Maas and Hoffmann [50] reported that the rice plant can maintain a normal yield up to a salinity level of $3 \mathrm{dSm}^{-1}$, above which the yield declines by $12 \%$ with increase in each unit of salinity. Rice cultivation which is predominant in the area is impeded by tidal water incursion into the arable lands, which results in water-logging during the Kharif (monsoon) cultivation, whereas the Boro (winter) cultivation is obstructed by severe salt stress, owing to the capillary rise of saline groundwater into the paddy fields [72].

Farmers in the area have adapted to the abiotic stresses involving soil salinity, submergence and water-logging by cultivating rice varieties which are best suited for the local conditions. However, in the recent times climate change has severely impeded the local agronomic practices. In the last two decades despite of overall increase in monsoon rainfall, the pre- and post-monsoon rainfall have sharply declined with time (Fig. 3). The pre-monsoon rainfall is essential for reducing the salinity levels of the groundwater before commencement of the Aman (monsoon) cultivation, whereas the post-monsoon rainfall is required for maintaining adequate soil moisture level, which is essential for rice sowing during Boro season from the middle of November. The decline of the pre- and postmonsoon rainfall (as a resultant of the climate change) has increased the soil salinity levels, especially during the ricegrowing seasons. As a result, the productivity of preferred rice varieties along with local fruits and vegetables has been severely hampered. The severe impact of climate change and its reciprocal impact upon soil salinity have been reconfirmed by the rural communities of Gosaba, Kultali, Kakdwip, Sagar, Patharpratima and Namkhana, as shown in the works of Sahana et al. [70].

The problem associated with soil salinity is further magnified owing to the frequently occurring cyclonic storms observed during the monsoon season. In recent times, recurrent super cyclones have devastated the region, resulting in ingress of saline seawater through tidal waves flooding the mainland. Owing to such shifts in salinity levels, the stability of crop production along with food security can be gravely compromised unless climate-smart cultivars and strategic agricultural practices suited to the shifting climatic conditions are available to the farmers of the delta.

\subsection{Arsenic contamination of groundwater and its impact on agriculture:}

Arsenic (As) has been classified as a Group A human carcinogen by the U.S Environmental Protection Agency (EPA). Currently, the Public Health And Engineering Department, 
Fig. 3 Changes in the rainfall pattern in the Sundarban delta over last the two decades (a pre-monsoon, b monsoon, c post-monsoon) which are already quite evident [42], TRMM Tropical Rainfall Measuring Mission, IMD India Meteorological Department
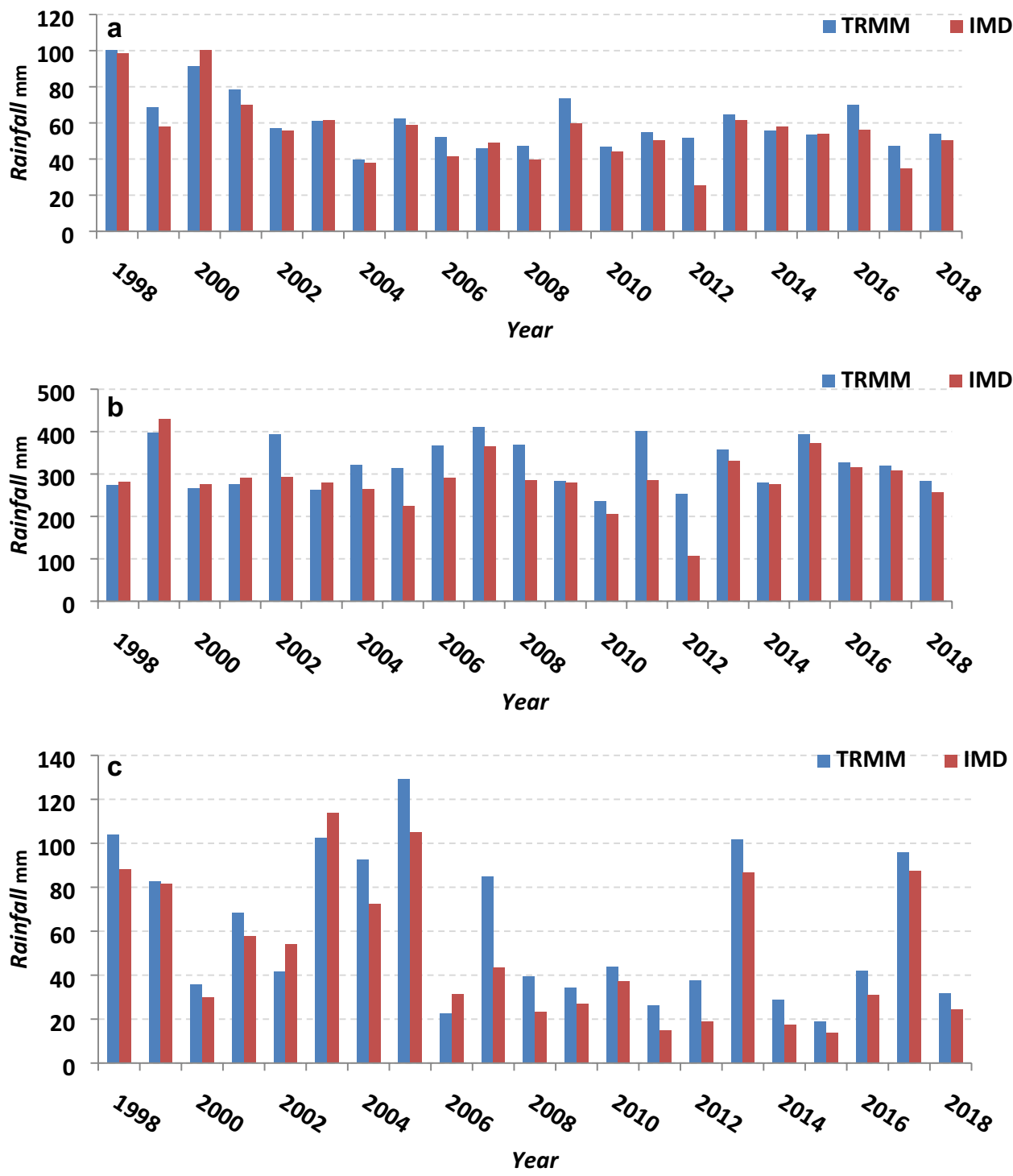

Govt. of West Bengal, India has identified 22 blocks of N.24 Pargana and 9 blocks of S.24 Parganas, of which eight blocks of the SBR showed groundwater arsenic levels exceeding $0.01 \mathrm{mg} / \mathrm{l}$ which is above the $\mathrm{WHO}$ permissible limits for drinking water (WHO, 2003) (Fig. 1).

Apart from the exposure to high arsenic pollution through the consumption of contaminated water, the population in the delta is also vulnerable to arsenic contamination through their regular dietary consumption of rice, vegetables and fruits produced in the region using arsenic-contaminated groundwater for irrigation [14]. Studies by Norra et al. [62] indicate that long-term use of As-contaminated water from the shallow aquifers tends to magnify the As levels on the top soils, predominantly in the paddy fields as observed in various locations of the Sundarban Delta. Earlier investigations across various endemic zones situated in the Bengal basin reveal that biomagnification of As in the human food chain is a strong possibility, with rice and rice-based products playing a key role in the process (Table 1). Arsenate (AsV) being a phosphate analog, it is readily available to plants via phosphate transporters. Under aerobic conditions, arsenate can be extracted and translocated by phosphate transporters like OsPT8 in rice [75, 84]. Under flooded conditions (anaerobic), arsenite (AsIII) is more readily available to rice plants than Arsenate [88]. In rice, the arsenite influx occurs via aquaporin channels with the help of OsNIP3,2 (nodulin 26-like intrinsic membrane proteins) [23] Also, the silicon transporters Lsi1 and Lsi2 in combination play a major role in the uptake and translocation of silicon and arsenite into the plant $[49,87]$. The phosphate transporters and nodulin 26 like intrinsic membrane proteins are highly conserved genomic regions in plants [83]. Thus, apart from rice, a wide range of cultivated crops can uptake arsenic and 
Table 1 Arsenic contamination in various food sources cultivated/exposed to high levels of As through water extracted from Holocene aquifers of Bengal Basin

\begin{tabular}{|c|c|c|c|c|}
\hline Sl. no & Type of crops/food items & $\begin{array}{l}\text { Average As } \\
\text { conc. (mg/ } \\
\mathrm{kg})\end{array}$ & References & Remarks \\
\hline 1 & Rice (raw grain) & 0.5 & Biswas et al. [11] & $\begin{array}{l}\text { As-contaminated irrigated water from endemic zones signifi- } \\
\text { cantly increased grain As level compared to non-endemic } \\
\text { zones in West Bengal, India }\end{array}$ \\
\hline \multirow[t]{2}{*}{2} & Rice (raw grain) & 0.182 & \multirow[t]{2}{*}{ Chowdhury et al. [28] } & \multirow{2}{*}{$\begin{array}{l}\text { Grain As increased in cooked rice when prepared using water } \\
\text { containing As at concentrations of } 0.084 \mathrm{mg} / \mathrm{l}\end{array}$} \\
\hline & Cooked Rice & 0.243 & & \\
\hline \multirow[t]{3}{*}{3} & Puffed rice & 0.226 & \multirow[t]{3}{*}{ Chowdhury et al. [27] } & \multirow{3}{*}{$\begin{array}{l}\text { Post-harvest processing using As-contaminated water increased } \\
\text { As levels in Rice and Rice-based food products in the endemic } \\
\text { zones }\end{array}$} \\
\hline & Parched rice & 0.351 & & \\
\hline & Parboiled rice & 0.186 & & \\
\hline \multirow[t]{2}{*}{4} & Rice (boro) & 1.12 & \multirow[t]{2}{*}{ Chowdhury et al. [29] } & \multirow{2}{*}{$\begin{array}{l}\text { Boro (dry season) paddy showed significantly higher grain As } \\
\text { concentrations }\end{array}$} \\
\hline & Rice (aman) & 0.35 & & \\
\hline 5 & Green vegetables & 0.021 & \multirow[t]{2}{*}{ Roychowdhury et al. [69] } & \multirow{2}{*}{$\begin{array}{l}\text { Trace amounts of As detected in vegetables and spices culti- } \\
\text { vated using As-contaminated irrigation waters from endemic } \\
\text { zones of West Bengal, India }\end{array}$} \\
\hline 6 & Spices & 0.202 & & \\
\hline 7 & Straw (fodder) & 2.748 & \multirow[t]{4}{*}{ Datta et al. [36] } & \multirow{4}{*}{$\begin{array}{l}\text { Arsenic detected in cattle and poultry products, sampled from } \\
\text { livestock exposed to As-contaminated straw as fodder as well } \\
\text { as water in the endemic zones of West Bengal }\end{array}$} \\
\hline 8 & Milk & 0.057 & & \\
\hline 9 & Poultry egg albumen & 0.062 & & \\
\hline 10 & Poultry egg yolk & 0.111 & & \\
\hline
\end{tabular}

translocate it to a varying extent using similar transporters. Roychowdhury et al. [69] showed bioaccumulation of arsenic in different vegetables and spices, which were cultivated using As-contaminated irrigation water extracted from the Holocene aquifers of the Bengal delta (Table 1).

Extensive studies conducted by Rahman et al. [65] suggested that people of N 24 Pargana (part of the delta) being exposed to arsenic toxicity through drinking contaminated water along with dietary exposure through rice and vegetables have led to several diseases. Some of the pathological manifestations included arsenic-induced skin lesions which in later stages lead to cancer and morbidity. Epidemiological studies conducted by Das et al. [33], Mazumder et al. [57], Mazumder et al. [56] and Upadhyay et al. [81] identified the health impacts of arsenic exposure in the Ganges delta (Sundarbans) through the consumption of As-contaminated drinking water as well as food grains especially rice, which were exposed to As-contaminated groundwater from the local holocene aquifers primarily through irrigation and the cooking process.

Arsenic exposure through rice and vegetables has also been reported in the works of Signes-Pastor et al. [76] in N 24 Pargana of West Bengal. Apart from crops and drinking water, livestock and poultry are also considered as potential sources of arsenic exposure in the delta. Datta et al. [36] reported toxic levels of arsenic in egg, meat and milk products of livestock exposed to chronic levels of arsenic in the contaminated areas (Table 1).
The investigation suggested that arsenic entry into the livestock primarily occurs through the consumption of contaminated fodder and drinking water; which was confirmed by the detectable levels of arsenic recorded in the milk, urine and feces samples collected from the livestock. Similarly, poultry birds reared in endemic zones exhibited high accumulation of As in egg yolk, albumen and meat.

The various studies reported above indicate that biomagnifications of arsenic into the human food chain is a strong possibility which can leave a grave impact on the overall health and survivability of the people in the delta. Although interventions have been implemented for combating the infusion of As through drinking water supply, by the collaborative efforts of Public health engineering department (PHED), Unicef, Universities and other government and non-government organizations [35], comprehensive efforts toward addressing arsenic biomagnifications through food sources resourced from the area is yet to be executed. Thus, mitigation policies must consider multiple aspects which influence the issue. Firstly restriction in the use of groundwater extracted from the arsenic-contaminated shallow aquifers must be enforced. Secondly, plant breeding strategies can be exploited for developing grain and fodder crops which can restrict the uptake and translocation of arsenic into their consumable parts. 


\subsection{Water pollution from agricultural chemicals}

One of the less investigated phenomena which require the immediate attention of researchers and policymakers is the possible environmental hazard which can be triggered by adopting calamitous farming practices in the delta. The delta landform mostly comprises farmers with small and marginal land holdings, predominantly comprising of paddy fields with inadequate agricultural drainage infrastructures $[22,53,54]$. The post-green revolution cultivars grown in the area are subjected to heavy doses of nitrogen in the form of Urea or other compound fertilizers for maximum yield along with organochlorine, organophosphate and carbamate pesticides and herbicides for enhancing productivity. In the absence of proper drainage, the agricultural wastes are carried into the freshwater systems of the delta by surface runoff. Sarkar and Bhattacharya [73] noted an upsurge of nitrate and phosphate levels in the water bodies of Sundarbans during the monsoon period between the month of July to October. It was presumed that the excess nitrate and phosphates were carried by runoff from the adjacent agricultural fields. Similar phenomena in the Sundarbans were also reported by Mitra [59]. Furthermore, residues of organochlorine pesticides in the sediment cores of Indian Sundarbans were reported in the works of Bhattacharya et al. [9]. Agricultural pollutants corresponding to phosphate-based pesticides and herbicides which showed significant influence upon bacterial biodiversity at specific sites of the Sundarban delta were evinced in the works of Chakraborty et al. [19].

Though research on the possible impact of water pollution in the SBR and the delta is limited; in recent times, the $60,000 \mathrm{Km}^{2}$ long dead zones in the Bay of Bengal [47], [15] prioritize research on the concerning issue. A similar phenomenon has been earlier recorded in the Gulf of Mexico, where large Dead zones could be observed as a result of runoff from US Corn Belt, which were drained by the Mississippi river system into the Gulf $[52,68,82]$. Possibilities of water pollution in the Sundarban delta from agricultural wastes are further confirmed from the studies conducted by De et al. [37]. The investigation showed a distinctive increase in the abundance of phytoplankton species in recent times compared to earlier studies conducted in the same areas of the Sunderban. Among the various environmental components, eutrophication of water bodies has been observed as a key factor which contributed to the abundance of phytoplanktons in the estuaries. In addition to fertilizer and pesticide residues, deposition and accumulation of heavy metals within and beyond the geographical limits of the Sundarbans are considered to be a matter of utmost ecological significance. Bhattacharya et al. [8] revealed that significantly high concentrations of $\mathrm{Mn}, \mathrm{Cr} \mathrm{Zn}, \mathrm{Ni}, \mathrm{Cu}, \mathrm{Co}, \mathrm{Cd}$ and $\mathrm{Pb}$ were quite evident in the surface waters, acquired from multiple locations in the Indian Sundarbans (Table 2). Similarly, recent investigations by Chanda et al. [21] indicated that selective accumulation of heavy metals (viz. $\mathrm{Zn}, \mathrm{Pb}$, $\mathrm{Cu}, \mathrm{Cr}, \mathrm{Ni}, \mathrm{Cd}$ and $\mathrm{As}$ ) were recorded within the vicinity of Sundarban mangrove patches (Table 2). Furthermore, the study revealed that agglomeration and bioaccumulation of heavy metals were often influenced by the levels of organic carbon present in the soil sediments. Mangrove litter and estuarine-borne phytoplanktons are some of the major sources of organic matter, especially organic carbon detected in the Sundarban delta [67]. The investigation revealed a synergistic influence of soil organic carbon upon the accumulation of $\mathrm{As}, \mathrm{Cu}$ and $\mathrm{Cr}$ within the vicinity of Avicennia marina mangrove patches of Sundarbans. At the same time, a negative association between As concentrations and organic carbon levels was observed at the location dominated by the mangrove species Excoecaria agallocha. A multitude of complex factors may influence such observations. One explanation indicates that areas where positive association was observed between metalloid concentrations and organic carbon levels, formation of complexes between organic matter and heavy metals can be expected. Such metalloid complexes are often unavailable for translocation by plant roots which results in their retention and increased concentrations within the soil sediments [3]. On the other hand, the E. agallocha dominated sites exhibited a negative correlation between organic carbon and As concentration in the soil sediments, which may indicate a limited interaction between the two at the given site. A similar study conducted at the Sundarbans by Chowdhury et al. [30] revealed E. agallocha as an efficient bioaccumulator of metalloid $\mathrm{Zn}$ and $\mathrm{Cd}$. As a whole, the various observations clearly indicate that bioaccumulation of heavy metals and agrochemical compounds is a strong possibility in the Sundarbans. Such observations can be a result of natural as well as anthropogenic factors, as revealed by the above mentioned investigations. However, empirical evidences often indicate that heavy metal accumulation in natural ecosystems can be very often triggered by anthropogenic interventions. In the context of Indian Sundarbans, a large-scale study conducted across sixteen locations revealed alarmingly high concentration of $\mathrm{Pb}, \mathrm{Cd}$ and $\mathrm{Ni}$ in the waters of the distributaries draining the region [26]. The $\mathrm{Pb}$ and $\mathrm{Ni}$ pollution can be primarily attributed to the anthropogenic activities such as fuel seepage from the motorboats and large ferries used for transport. On the other hand, $\mathrm{Cd}$ pollution can possibly be triggered by the improper disposal of rechargeable batteries (used for supporting electricity shortage in the areas).

Similarly, in terms of agricultural practices heavy metal bioaccumulation can be driven by non-judicious use of 
Table 2 Pollutants detected across various locations in the Indian Sundarbans

\begin{tabular}{|c|c|c|c|c|c|}
\hline SI. no. & Pollutants & $\begin{array}{l}\text { Mean concentrations ( } \mu \mathrm{g} / \mathrm{g} \\
\text { dry weight) }\end{array}$ & Locations & References & Remarks \\
\hline 1 & $\begin{array}{l}\text { Hexachloro- } \\
\text { cyclohex- } \\
\text { ane }(\mathrm{HCH})\end{array}$ & 0.134 & $\begin{array}{l}\text { Hugli estuary adjoining } \\
\text { Sundarban mangrove forest }\end{array}$ & Bhattacharya et al. [9] & $\begin{array}{l}\mathrm{HCH} \text { and DDT are known } \\
\text { insecticides, detected in } \\
\text { surface sediments }\end{array}$ \\
\hline 2 & $\begin{array}{l}\text { Dichlorodi- } \\
\text { phenyl- } \\
\text { trichlo- } \\
\text { roethane } \\
\text { (DDT) }\end{array}$ & 0.058 & & & \\
\hline \multirow[t]{9}{*}{3} & Trace Metals & Mean concentrations $(\mu \mathrm{g} / \mathrm{l})$ & \multirow{9}{*}{$\begin{array}{l}\text { Jambu Island, Gangasagar } \\
\text { Chemagari, Lot 8, Canning } \\
\text { and Dhamakhali }\end{array}$} & \multirow[t]{9}{*}{ Bhattacharya et al. [8] } & \multirow{9}{*}{$\begin{array}{l}\text { Dissolved trace metals like } \\
\mathrm{Cu} \text { and } \mathrm{Zn} \text { were observed } \\
\text { in Surface water samples o } \\
\text { Sundarban delta. High Cu } \\
\text { and } \mathrm{Zn} \text { can be contributed } \\
\text { to } \mathrm{Cu} \text {-based insecticides } \\
\text { and } \mathrm{ZnSO}_{4} \text {-based fertilizers } \\
\text { used in the region }\end{array}$} \\
\hline & $\mathrm{Mn}$ & 223 & & & \\
\hline & $\mathrm{Cr}$ & 39.30 & & & \\
\hline & $\mathrm{Zn}$ & 57.25 & & & \\
\hline & $\mathrm{Ni}$ & 36.23 & & & \\
\hline & $\mathrm{Cu}$ & 33.88 & & & \\
\hline & Co & 20.73 & & & \\
\hline & $\mathrm{Cd}$ & 5.53 & & & \\
\hline & $\mathrm{Pb}$ & 14.76 & & & \\
\hline \multirow[t]{8}{*}{4} & Heavy Metals & Mean concentrations $(\mathrm{mg} / \mathrm{kg})$ & \multirow{8}{*}{$\begin{array}{l}\text { Mixed mangrove patches of } \\
\text { Jharkhali Island, Sundarban }\end{array}$} & \multirow[t]{8}{*}{ Chanda et al. [21] } & \multirow{8}{*}{$\begin{array}{l}\text { Analysis of mangrove } \\
\text { sediment samples revealed } \\
\text { variable accumulation of } \\
\text { heavy metals depending } \\
\text { on speciation of man- } \\
\text { groves, located in the } \\
\text { Sundarban mangrove } \\
\text { patches }\end{array}$} \\
\hline & $\mathrm{Zn}$ & 153 & & & \\
\hline & $\mathrm{Pb}$ & 30.4 & & & \\
\hline & $\mathrm{Cu}$ & 76.5 & & & \\
\hline & $\mathrm{Cr}$ & 49.8 & & & \\
\hline & $\mathrm{Ni}$ & 42.6 & & & \\
\hline & $\mathrm{Cd}$ & 1.0 & & & \\
\hline & As & 3.3 & & & \\
\hline
\end{tabular}

agricultural inputs [80]. An upsurge of $\mathrm{Cu}$ and $\mathrm{Zn}$ (as indicated across different areas of Sundarban in Table 2) are often linked with excessive use of copper-based pesticides and $\mathrm{ZnSO}_{4}$ fertilizers, respectively [8]. Thus, effective strategies must be adopted for regulating water pollution from agricultural chemicals as well as other anthropogenic factors in the delta, which can ultimately ensure the conservation of water resources vital for sustenance of flora and fauna in the region.

The overall study discusses the threefold problems which are integral to the Sundarbans. Although the issues may appear to be discrete, they are necessarily intertwined as illustrated in the schematic model discussed in Fig. 4.

\section{Mitigation strategies for addressing the problems in the delta}

For sustaining agricultural practices in the delta, mitigation policies can be classified into short-term mitigation policies with immediate results and long-term risk aversion strategies which are in imminent need for facing the impact of salinity, arsenic contamination and water pollution in the long run.

\subsection{Mitigation strategies for salinity and water pollution using traditional land races}

Given the knowledge and years of experience in cultivation, the farmers of the Sundarbans have selected the best adapted rice cultivars that are most suited to the geographical location, water availability and soil conditions. Rice varieties like Dudheswar, Patnai, Gobindobhog, Swarna, etc. are popular during Aman in rainy season, owing to their high marketability and profitability. Cultivation during Aman season is predominantly dependent on rainwater [53, 54, 74]. Occasionally, water from the sources like ponds or streams in the neighborhood is extracted for irrigation by the help of small pumps. During Boro season, areas where water is readily available, rice varieties like Basmati, Shatabdi, N. Sankar, IR64 and few commercial hybrids are cultivated. Farmers during Boro season primarily rely on pond water and groundwater from shallow aquifers which are extracted using shallow tube wells with the help of small centrifugal pumps [16]. As discussed earlier, 


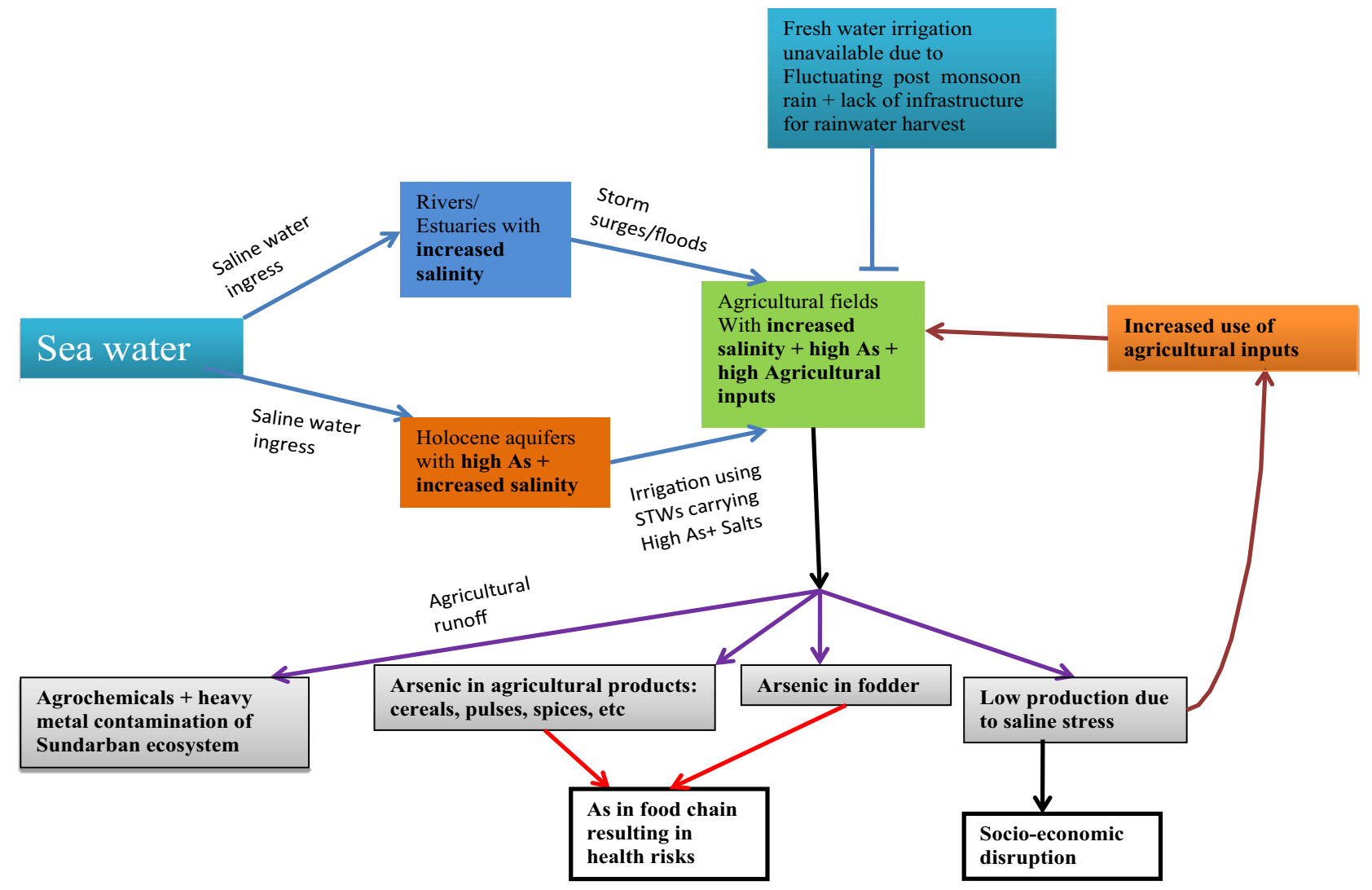

Fig. 4 Model showing threefold problems of arsenic, salinity and water pollution associated with agriculture in the Sundarban delta. Arrow indicates contributing factors

the rise in salinity levels, induced by climate change, has immensely impacted the productivity of the above mentioned popular rice varieties in the region. Under such circumstances, "bet-hedging" strategies may possibly be one of the best ways to manage the situation. Denison [40] explains bet hedging in the context of food production as "sacrificing the best imaginable outcome to avoid the risk of the worst imaginable one."The approach emphasizes on diversifying the choice of cultivars in order to maintain a sustainable crop production in the long run and avoiding complete dependence upon the cultivars which fetch the highest profits only under conducive conditions. In other words, farmers must invest a part of their resources in cultivars which are more adapted to extreme conditions and can effectively prevent complete crop failure under severe conditions.

In case of surviving the extreme conditions of Sunderbans, the rice landraces which are either lost or no longer cultivated in the areas might have the highest chances of survival. Indigenous rice landraces like SadaGetu, LalGetu, Talmugur, Nona Bokra, Matla, Hogla and Hamilton that are salt tolerant or show high resilience against salinity have been of great value even during the havoc of cyclone Aila in 2009. The devastating effect of the cyclone led to seawater incursion into the mainland across several low-lying areas. After the water receded, the soil conditions across several acres of paddy fields became extremely hostile for any kind of cultivation owing to the extreme levels of salinity, as observed by Debnath [39], Chakraborty [20], Kar and Bandyopadhyay [48]. Under such circumstances, the traditional salt tolerant rice land races were the only ones that survived, while none of the high $\mathrm{N}_{2}$ responsive, post-green revolution semi-dwarf rice cultivars could tolerate the extreme saline conditions [38]. Thus, popularization and conservation of such climate-resilient rice landraces may be quite efficacious in combating the saline stress across the Sundarban delta. Apart from the re-introduction of salinity tolerant indigenous rice, the approach of subsurface desalinization as proposed by Hazra et al. [45] can be exploited. The combined approach can act as a game changer in the salinity-affected blocks of the Sundarban delta.

The traditional variety of rice landraces can be effectively functional in restricting water pollution from agricultural chemicals. It has been noted that traditional landraces are well suited to the indigenous method 
of cultivation and can be grown successfully without any additional inputs [61]. Natural selection along with farmer's selection over decades has endowed the landraces with resistance toward locally prevailing pests and pathogens [32]. Owing to the adaptive advantage, the diverse native landraces do not require chemical fertilizers, pesticides or herbicides which can exponentially reduce the cost of cultivation. Among other biotic stresses weed infestations in the low land rice belts are quite common. But the phenotype of the modern semi-dwarf rice cultivars is not conducive for competing against the weed infestation. For avoiding weeds, farmers use high doses of organophosphorus herbicides among which Glyphosate has been quite popular. The rice landraces have unique ability of suppressing weeds owing to their competitive nature which has been perfected by natural selection. The intermediate to tall height with large leaf area index and profuse tillering helps the plant in competing against weeds. As a result, the indigenous rice landraces do not require harmful chemical herbicides. Although the yield potential of the traditional rice varieties discussed here is considered to be lower compared to the high $\mathrm{N}_{2}$ responsive post-green revolution cultivars, the lower yield can be compensated by their superior palatability and urban demand, especially for varieties like Dudheswar, Gobindobhog, Gopalbhog, Kanakchur (for making local popular sweet dish "Moa"), Chamarmani, etc., cultivated in the region [64].

Thus, promoting the cultivation of traditional landraces, conservation and rejuvenation of the traditional farming practices along with adoption of organic farming can reduce the total input of agrochemicals into the paddy fields, which in turn can significantly help in lessening the ingress of harmful agricultural chemicals into the aquatic environment like lakes, rivers and estuaries of the delta.

In the context of sustainable agricultural practices, organic farming can prove to be immensely beneficial, especially for reducing pollution from agricultural wastes. Chowdhury et al. (2016c) revealed the efficacy of designing group-based training programs; where essential knowledge related to organic farming (namely integrated nutrient management, application of manure, composting techniques, utilization of vermicomposts and application of herbal pesticides like neem oil) were communicated to a group of vulnerable families in the Sundarbans. Similar capacity building exercises aimed at creating awareness among the inhabitants about the benefits of organic farming along with cultivation of indigenous landraces suited to such organic mode of cultivation can possibly assure long-term sustainability in the delta.

\section{SN Applied Sciences}

\subsection{Mitigation strategies for arsenic contamination in the food chain}

Arsenic accumulation in rice grain is predominantly affected by the irrigation water lifted from arsenic-contaminated shallow aquifers. Thus, mitigation policies must be primarily focused on judicious aquifer management such as utilization of arsenic-free water reserves for irrigation. One of the ways this can be achieved is by widespread practice of harvesting rainwater in ponds, tanks and canals. Secondly, identification and selection of appropriate rice cultivars can effectively help in reducing grain arsenic levels, since variation among rice cultivars has been observed with respect to arsenic translocation. Finally, all possible pathways leading to As biomagnifications must be considered and addressed in relation to the potential threats it poses to human and animals.

\subsection{Mitigation approaches involving use of As-free irrigation water}

Rice cultivation during the boro season is greatly dependent upon groundwater irrigation using STWs. This extensive use of groundwater must be replaced by As-free freshwater resources from Surface irrigation or harvested rainwater from ponds or reservoirs. But prior to utilization of such above ground water reserves, extensive examination of As levels in such water resources must be considered. Studies by Majumder et al. [51] indicate a possible source of As contamination of above ground freshwater sources from retting process of Jute cultivated in the As-contaminated areas of the delta. The study shows an increase in pond As content by 0.2 to $2.0 \mathrm{mg} \mathrm{L}^{-1}$ which significantly exceeds the recommended safety threshold. Thus, extensive testing of above ground water resources by Government supported programs must be undertaken and possible contaminated water bodies are required to be flagged. More ponds and reservoirs for rainwater harvest must be constructed, especially in the catchment areas for increasing freshwater sources in the region. Furthermore, large-scale measures like renovation of already constructed canals, reconnection of decayed river channels with existing river systems by dredging, along with creation of dams can restore the freshwater sources in the Indian Sundarbans [46]. Such measures can reduce the farmer's dependence upon As-contaminated groundwater, extracted using Shallow tube wells during the Rabi seasons.

Since freshwater has to be economically used, the approach of "water productivity" can be applied for selection of suitable cultivars. Bouman et al. [13] classified water productivity into $\mathrm{W}_{\mathrm{PT}}$ (weight of grains over cumulative weight of water transpired), $\mathrm{WP}_{\mathrm{ET}}$ (weight of grains over 
cumulative weight of water evapotranspired), $\mathrm{WP}_{1}$ (weight of grains over cumulative weight of water inputs by irrigation.), $\mathrm{WP}_{\mathrm{IR}}$ (weight of grains over cumulative weight of water inputs by irrigation and rain.). Among these parameters, $\mathrm{WP}_{\mathbb{I}}$ (weight of grains over the cumulative weight of water inputs by irrigation and rain) can be utilized for finding the best responsive rice genotypes for the region; especially for the boro cultivation.

Apart from judicious use of water, the efficacy of aerobic rice cultivation and AWD (Alternate Wetting and Drying) in decreasing arsenic uptake has been noted in the works of Xu et al. [86] and Das et al. [34], respectively. In case of crops and vegetables which can be cultivated in unsaturated soil, drip irrigation and sprinkler irrigation systems using harvested rainwater or As-free surface water may drastically reduce As levels in the soil. However such measures may not be economically feasible for the marginal farmers of the deltaic region. Under such circumstances, financial support to the farmers from State and International agencies as well as agricultural subsidy programs can encourage such farming practices.

\subsection{Mitigation approaches using biological measures}

In the context of plant breeding, a wide variety of rice cultivars have been identified which showed a lower range of grain arsenic accumulation, when evaluated across different As-contaminated regions of India and Bangladesh. Bhattacharya et al. [10] suggested low arsenic uptake in a popular landrace Megi when evaluated across different arsenic-contaminated blocks of Nadia district in West Bengal. In a similar study, Norton et al. [63] identified low arsenic uptake in varieties like CT9993-5-10-1-M, Lemont, Azucena and Te-qing, tested across two locations in Bangladesh. In recent times, the cultivar $\mathrm{CN}-1794-2-$ CSIR-NBRI named "Muktashri" has been developed by collaborative efforts of Rice Research Station, Chinsurah and CSIR-National Botanical Research Institute, Lucknow [4]. The variety has been designated as a low accumulator of grain arsenic.

In case of rice, the plant breeding approaches have delivered some promising solution to the problem, yet similar efforts considering other crops and vegetables popular in the area are limited. Codex Alimentarius Commission, the UN body responsible for setting food safety standards, jointly run by World Health Organization (WHO) and Food and Agriculture Organization (FAO) has set the limit of arsenic levels in polished rice to $0.2 \mathrm{mg} / \mathrm{kg}$ [31]. Though the polished rice of many of the varieties developed may contain arsenic lower than the permissible limit, yet when consumed as a part of a diet comprising of vegetables, pulses, meat and milk products exposed to
As contamination, the overall As intake may reach alarming levels. Samal et al. [71] showed that the total arsenic uptake through the dietary intake in adults and children was $560 \mu \mathrm{g} /$ day and $393 \mu \mathrm{g} /$ day, respectively, in arseniccontaminated areas of Nadia districts, West Bengal. The study suggested that arsenic retention in adults and children was $284 \mu \mathrm{g} /$ day and $239 \mu \mathrm{g} /$ day, respectively. Thus, mitigation policies which are mostly focused on reducing As contamination of rice must be extended to other crops cultivated in the area. One can say that independent efforts to avert the crisis may not be enough to address the trepidation set off by arsenic contamination. Plant breeding approaches for controlling As levels in rice, vegetables, pulses and oilseeds must go hand in hand with cultural practices that limit water input from arsenic-contaminated sources in the delta. At the same time, fodder for livestock must avoid arsenic-contaminated plant by-products like paddy straw, which contains considerably higher levels of arsenic than the milled grains [1]. Such practices can lead to the indirect entry of arsenic into the food chain through meat or milk. Instead, fodder crops like hybrid Napier, fodder Sorghum and tree fodder like Subabul can be cultivated under rainfed conditions for ensuring As-free fodder for the livestock in the area.

\subsection{Evolutionary plant breeding for long-term sustainability}

For ensuring survival of a species, very few measures have been observed to be as effective as natural selection. Mather [55] suggested that the polygenic balances that have been established by natural selections act as a constant driving force, responsible for reshuffling and reestablishment of new genic balances. Among the various breeding approaches available, the Bulk Population Breeding has been proven to be the most extensive method for exploiting natural selection. Suneson [77] analyzed the effects of natural selection at different generations of the Composite cross II in Barley obtained by using Bulk Population Breeding. Based on the observations among individual lines selected at $F_{12}, F_{20}$ and $F_{24}$ generations of the Composite Cross II, Allard [2] suggested that the yield of the Bulk population increases steadily with each generation. With respect to environmental interactions, Allard [2] in his study indicates that morphological features like plant height, maturity and adaptation of a composite population are rapidly adjusted by natural selection to ensure maximum fitness under the environment in which the population has been subjected. Thus, the approach of Bulk Population breeding can be effective for obtaining adaptable genotypes for the deltaic regions of Sundarban. Success of such breeding approach was recorded among pure lines derived from the composite crosses by Suneson 
[77]. Selections from $\mathrm{F}_{20}$ to $\mathrm{F}_{24}$ generations out-yielded the highest ranking variety Atlas and few lines exhibited resistance to major diseases linked to Barley. In recent times, similar breeding strategy has been initiated by ICARDA (International Center for Agricultural Research in the Dry Areas) for Barley and Durum Wheat [18].

While designing a long-term breeding program for the Sundarbans, abiotic factors can be brought as the focal point of attention. Parental lines possessing desirable genes for salinity along with high yield, desirable maturation and palatability can be cautiously selected and crossed in all combinations to develop a Composite population which can be cultivated under the deltaic conditions of the Sundarbans. One of the advantages of the Evolutionary plant breeding is that the agronomically undesirable alleles which are often deleterious to the survival of the populations under the given environment, will be rapidly eliminated by natural selection, as has been observed in the composite crosses of Suneson and Stevens [78]. Thus, the alleles which are susceptible to salinity or other abiotic and biotic factors prevalent in the region can be expected to be significantly reduced in successive generations. In addition to natural selection, negative selection by removal of unwanted phenotypes from the composite population can be practiced for obtaining desirable pure lines in the later generations. Variability among the recombinants can be further increased by repeated hybridization among the sergeants, especially when homozygosity sets in during the later generations.

Evolutionary plant breeding methods can be equally effective in developing crops suited to low input farming systems, which in turn can reduce the risks involved with water pollution from agrochemicals in the Sundarban delta. Murphy et al. [60] suggested Evolutionary Participatory Plant Breeding method, which takes the farmer's selection criteria into account for obtaining pure lines that are adapted to traditional low input farming systems. Such breeding approaches can be viewed as a potential alternative to other conventional breeding practices which involve selection of segregants grown under high input conditions. Similarly, composite crosses developed for Sundarban ecosystem can be subjected to traditional farming systems which are popular among the local farmers. Pure lines extracted from such bulk populations can be expected to be highly responsive to traditional organic or low input practices. In the long run, such cultivars can reduce the input of agrochemicals in the cultivated fields, ultimately reducing the risk of water pollution from farm runoff into nearby water bodies of the delta.

One of the major drawbacks involving Bulk population breeding is that the natural selection can only act upon traits which are essential for the survival of individual genotype. Thus, traits like low grain arsenic or superior grain quality may not be selected upon, unless it directly influences the fitness of individual genotypes constituting the population. In such cases, parents with the desirable alleles must be included in the breeding program. Additionally, artificial selections can be performed in the advanced generations for increasing the frequency of the desirable genotypes in the bulk population. For ensuring low accumulation of arsenic in grains or other consumed parts, parents showing such properties can be included in the mating design. Rice cultivars discussed earlier in the report can be selected as potential parents for obtaining composite crosses designed for the Sundarban delta. Additionally, artificial selection can be pursued by cultivating the bulk population using water management practices like AWD or intermittent irrigation. Such selection regime can increase the availability of lines adapted to such practices during the later generations. Pure lines extracted from such bulks should require less input of water, thereby reducing the necessity of using excess groundwater from arsenic-contaminated shallow aquifers in the Sundarbans.

For grain quality traits required for marketability of the crops, Murphy et al. [60] emphasize on selection of parents with desirable quality parameters for ensuring higher frequency of progenies with desired quality traits in the segregating generations. Allard [2] proposes purging of unwanted traits in a Bulk population by removing unwanted genotypes from the population at various generations. Such practices can ensure that the frequency of desirable alleles increases exponentially in each generation especially when less desired phenotypes are more competitive. Thus, locally adapted rice varieties like Chamarmani, Dudheswar, Basmati, etc. which are known for their quality traits can be exploited as parents of the Bulk population for ensuring desirable grain qualities among the hybrids.

\section{Conclusions}

The problems of salinity, arsenic contamination and water pollution though apparently appear to be unassociated, but it seems that availability of freshwater is the critical point that remains at the heart of the three problems. Judicious use of available freshwater resources must be in partnership with selection of adaptable cultivars that can sustain agriculture under the given conditions. While facing the issues of salt stress and water pollution from agrochemicals, the traditional land races have the adaptive advantage which can be employed for assured results. But in order to compete with the rising population, the low yield potential of the traditional varieties may not adequately address the crisis which the delta is currently undergoing. In the long run exploiting breeding 
strategies like "evolutionary plant breeding" may provide pure lines which can adapt to the new environmental conditions, and at the same time provide higher yield.

In case of arsenic contamination, mitigation strategies must focus on smart use of freshwater reserves in the form of rainwater harvesting or surface irrigation from arsenicfree resources. At the same time, cultivars which show low accumulation of As in the edible parts must be selected and recommended for the endemic zones. Further, the mitigation strategies aimed at reducing the arsenic concentration, which had primarily laid its emphasis on drinking water and rice consumption, must be extended to other vegetables, fruits and forage crops in order to restrict the various pathways which lead to biomagnification of As in the food chain.

Authors' contribution All the authors contributed toward preparation of the manuscript. The conceptualization was performed by Anirban Nath and Sugata Hazra. The literature search and data analysis were performed by Anirban Nath, Sourav Samanta and Saon Banerjee. The draft was prepared by Anirban Nath and critically revised by Sugata Hazra and Anamitra Anurag Danda.

Availability of data and materials All data generated or analyzed during this study are included in this published article.

\section{Declarations}

Conflict of interest On behalf of all authors, the corresponding author states that there is no conflict of interest.

Disclosures This work was accomplished under the project "Opportunities and trade-offs between the SDGs for food, welfare and the environment in deltas" supported by the NERC, UK and Department of Bio Technology, Govt. of India.

Open Access This article is licensed under a Creative Commons Attribution 4.0 International License, which permits use, sharing, adaptation, distribution and reproduction in any medium or format, as long as you give appropriate credit to the original author(s) and the source, provide a link to the Creative Commons licence, and indicate if changes were made. The images or other third party material in this article are included in the article's Creative Commons licence, unless indicated otherwise in a credit line to the material. If material is not included in the article's Creative Commons licence and your intended use is not permitted by statutory regulation or exceeds the permitted use, you will need to obtain permission directly from the copyright holder. To view a copy of this licence, visit http://creativecommons. org/licenses/by/4.0/

\section{References}

1. Abedin MJ, Cotter-Howells J, Meharg AA (2002) Arsenic uptake and accumulation in rice (Oryza sativa L.) irrigated with contaminated water. Plant Soil 240(2):311-319
2. Allard RW (1960) Principles of plant breeding. Wiley, Hoboken, pp 144-145

3. Antoniadis V, Levizou E, Shaheen SM, Ok YS, Sebastian A, Baum C, Prasad MN, Wenzel WW, Rinklebe J (2017) Trace elements in the soil-plant interface: phytoavailability, translocation, and phytoremediation-a review. Earth Sci Rev 171:621-645

4. Awasthi S, Chauhan R, Srivastava S, Tripathi RD (2017) The journey of arsenic from soil to grain in rice. Front Plant Sci 8:1007

5. Banerjee K (2013) Decadal change in the surface water salinity profile of Indian Sundarbans: a potential indicator of climate change. J Mar Sci Res Dev 2:3

6. Bhadra T, Hazra S, Kolay P, Sinha Roy SP (2013) Ground waterriver water interaction in Deltaic West Bengal with special reference to Sundarbans. In: Workshop on "Sustainable development and management of ground water in west Bengal and future of irrigation vis-à-vis arsenic contamination in ground water". Kolkata, vol 19, pp 138-142

7. Bhadra T, Hazra S, Ray SS, Barman BC (2020) Assessing the groundwater quality of the coastal aquifers of a vulnerable delta: a case study of the Sundarban Biosphere Reserve, India. Groundw Sustain Dev 11:100438

8. Bhattacharya BD, Nayak DC, Sarkar SK, Biswas SN, Rakshit D, Ahmed MK (2015) Distribution of dissolved trace metals in coastal regions of Indian Sundarban mangrove wetland: a multivariate approach. J Clean Prod 96:233-243

9. Bhattacharya B, Sarkar SK, Mukherjee N (2003) Organochlorine pesticide residues in sediments of a tropical mangrove estuary, India: implications for monitoring. Environ Int 29(5):587-592

10. Bhattacharya P, Samal AC, Majumdar J, Santra SC (2010) Accumulation of arsenic and its distribution in rice plant (Oryza sativa L.) in Gangetic West Bengal India. Paddy Water Environ $8(1): 63-70$

11. Biswas A, Biswas S, Das A, Roychowdhury T (2018) Spatial variability and competing dynamics of arsenic, selenium, iron and bioavailable phosphate from ground water and soil to paddy plant parts. Groundw Sustain Dev 7:328-335

12. Biswas S, Zaman S, Mitra A (2017) Soil characteristics of Indian Sundarbans: the designated world heritage site. Sci J Biomed Eng Biomed Sci 1:053-059

13. Bouman BAM, Lampayan RM, Tuong TP (2007) Water management in irrigated rice: coping with water scarcity. International Rice Research Institute, Los Baños, p 54

14. Brammer $\mathrm{H}$ (2008) Threat of arsenic to agriculture in India, Bangladesh and Nepal. Econ Polit Weekly 43:79-84

15. Bristow $L A$, Callbeck CM, Larsen M, Altabet MA, Dekaezemacker J, Forth M, Gauns M, Glud RN, Kuypers MM, Lavik G, Milucka J (2017) N 2 production rates limited by nitrite availability in the Bay of Bengal oxygen minimum zone. Nat Geosci 10(1):24

16. Burman D, Mahanta KK, Sarangi SK, Mandal S, Maji B, Mandal UK, Bandyopadhyay BK, Humphreys E, Sharma DK (2015) Effect of groundwater use on groundwater salinity, piezometric level and boro rice yield in the Sundarbans of West Bengal. In: Revitalizing the ganges coastal zone: turning science into policy and practices conference proceedings. CGIAR Challenge Program on Water and Food (CPWF), Colombo, Sri Lanka, p 61, 600 pp

17. Burman D, Maji B, Singh S, Mandal S, Sarangi SK, Bandyopadhyay BK et al (2018) Participatory evaluation guides the development and selection of farmers' preferred rice varieties for salt-and flood-affected coastal deltas of South and Southeast Asia. Field Crop Res 220:67-77

18. Ceccarelli S, Grando S, Maatougui M, Michael M, Slash M, Haghparast R, Rahmanian M, Taheri A, Al-Yassin A, Benbelkacem A, Labdi M (2010) Plant breeding and climate changes. J Agric Sci 148(6):627-637

19. Chakraborty A, Bera A, Mukherjee A, Basak $P$, Khan I, Mondal A, Roy A, Bhattacharyya A, SenGupta S, Roy D, Nag S (2015) 
Changing bacterial profile of Sundarbans, the world heritage mangrove: impact of anthropogenic interventions. World J Microbiol Biotechnol 31(4):593-610

20. Chakraborty $S$ (2015) Investigating the impact of severe cyclone Aila and the role of disaster management department-A study of Kultali block of Sundarban. Am J Theor Appl Bus 1(1):6-13

21. Chanda A, Swain S, Das S, Seal A, Ghosh T, Hazra S (2020) Spatial variation of heavy metal accumulation in the sediments adjacent to different mangrove plant species within a mixed mangrove stand. Soil Sediment Contam Int J. https://doi.org/ 10.1080/15320383.2020.1867505

22. Chattopadhyay K, Gayan S, Mondal I, Mishra SK, Mukherjee AK, Reddy JN, Marndi BC, Sarkar RK (2019) Stress tolerant rice and on-farm seed production ensure food security and livelihood to small and marginal farmers of Sundarbans (Indian site). SAARC J Agric 17(2):127-139

23. Chen Y, Sun SK, Tang Z, Liu G, Moore KL, Maathuis FJ et al (2017) The Nodulin 26-like intrinsic membrane protein OsNIP3; 2 is involved in arsenite uptake by lateral roots in rice. J Exp Bot 68(11):3007-3016

24. Chowdhury A, Sanyal P, Maiti SK (2016) Dynamics of mangrove diversity influenced by climate change and consequent accelerated sea level rise at Indian Sundarbans. Int J Glob Warm 9(4):486-506

25. Chowdhury A, Maiti SK (2016) Identifying the source and accessing the spatial variations, contamination status, conservation threats of heavy metal pollution in the river waters of Sunderban biosphere reserve, India. J Coast Conserv 20(3):257-269

26. Chowdhury A, Maiti SK, Bhattacharyya S (2016) How to communicate climate change 'impact and solutions' to vulnerable population of Indian Sundarbans? From theory to practice. SpringerPlus 5(1):1-17

27. Chowdhury NR, Ghosh S, Joardar M, Kar D, Roychowdhury $\mathrm{T}$ (2018) Impact of arsenic contaminated groundwater used during domestic scale post harvesting of paddy crop in West Bengal: arsenic partitioning in raw and parboiled whole grain. Chemosphere 211:173-184

28. Chowdhury NR, Das A, Joardar M, De A, Mridha D, Das R, Rahman MM, Roychowdhury $T$ (2020) Flow of arsenic between rice grain and water: Its interaction, accumulation and distribution in different fractions of cooked rice. Sci Total Environ 731:138937

29. Chowdhury NR, Das A, Mukherjee $M$, Swain S, Joardar M, De A, Mridha D, Roychowdhury T (2020) Monsoonal paddy cultivation with phase-wise arsenic distribution in exposed and control sites of West Bengal, alongside its assimilation in rice grain. J Hazard Mater 400:123206

30. Chowdhury R, Favas PJ, Pratas J, Jonathan MP, Ganesh PS, Sarkar SK (2015) Accumulation of trace metals by mangrove plants in Indian Sundarban Wetland: prospects for phytoremediation. Int J Phytorem 17(9):885-894

31. Codex Alimentarius Commission (2014) Report of the eighth session of the codex committee on contaminants in foods, The Hague, the Netherlands, 31 March-4 April 2014. ftp://ftp.fao. org/codex/Reports/Reports_2014/REP14_CFe.pdf

32. Corrado G, Rao R (2017) Towards the genomic basis of local adaptation in landraces. Diversity 9(4):51

33. Das D, Samanta G, Mandal BK, Chowdhury TR, Chanda CR, Chowdhury PP et al (1996) Arsenic in groundwater in six districts of West Bengal, India. Environ Geochem Health 18(1):5-15

34. Das S, Chou ML, Jean JS, Liu CC, Yang HJ (2016) Water management impacts on arsenic behavior and rhizosphere bacterial communities and activities in a rice agro-ecosystem. Sci Total Environ 542:642-652
35. Das TK (2019) Arsenic menace in West Bengal (India) and its mitigation through toolbox intervention: an experience to share. In: Ground water development-issues and sustainable solutions. Springer, Singapore, pp 305-314

36. Datta BK, Bhar MK, Patra PH, Majumdar D, Dey RR, Sarkar S, Mandal TK, Chakraborty AK (2012) Effect of environmental exposure of arsenic on cattle and poultry in Nadia district, West Bengal, India. Toxicol Int 19(1):59

37. De TK, De M, Das S, Chowdhury C, Ray R, Jana TK (2011) Phytoplankton abundance in relation to cultural eutrophication at the land-ocean boundary of Sunderbans, NE Coast of Bay of Bengal, India. J Environ Stud Sci 1(3):169

38. Deb, D. (2009). Valuing folk crop varieties for agroecology and food security. Biosci Resour 54-58

39. Debnath A (2013) Condition of agricultural productivity of Gosaba CD block, south 24 parganas, west Bengal, India after severe cyclone Aila. Int J Sci Res Publ 3(7):1-4

40. Denison RF (2012) Darwinian agriculture: how understanding evolution can improve agriculture. Princeton University Press, Princeton

41. Ghosh S, Mistri B (2020) Drainage induced waterlogging problem and its impact on farming system: a study in Gosaba Island, Sundarban, India. Spat Inf Res 1-13

42. Government of West Bengal (2011) West Bengal State action plan on climate change. http://moef.nic.in/downloads/publi cinformation/West-Bengal-SAPCC.pdf. Accessed on 26th June 2012

43. Hajra R, Ghosh T (2018) Agricultural productivity, household poverty and migration in the Indian Sundarban Delta. Elem Sci Anth 6(1):1-13

44. Hazra S, Ghosh T, DasGupta R, Sen G (2002) Sea level and associated changes in the Sundarbans. Sci Cult 68(9/12):309-321

45. Hazra S, Bhadra T, Ray SS (2019) Sustainable water resource management in the Sundarban biosphere reserve, India. In: Ground water development-issues and sustainable solutions. Springer, Singapore, pp 147-157

46. Hazra S, Khan MFA, Kansal ML, Barman BC, Bhadra T, Ghosh S, Saniruzzaman S, Chandniha SK (2015) Methodology for assessment of environmental flows for the Sundarbans ecosystem (a pilot study). IUCN-India (unpublished report)

47. Jayaraman KS (2016) Dead zone found in Bay of Bengal. Nature Asia

48. Kar NS, Bandyopadhyay S (2015) Tropical storm Aila in Gosaba block of Indian Sundarban: remote sensing based assessment of impact and recovery. Geogr Rev India 77(1):40-54

49. Ma JF, Yamaji N, Mitani N, Xu XY, Su YH, McGrath SP, Zhao FJ (2008) Transporters of arsenite in rice and their role in arsenic accumulation in rice grain. Proc Natl Acad Sci 105(29):9931-9935

50. Maas EV, Hoffman GJ (1977) Crop salt tolerance-current assessment. J Irrig Drain Div 103(2):115-134

51. Majumder A, Bairagya MD, Basu B, Gupta PC, Sarkar S (2013) Retting of jute grown in arsenic contaminated area and consequent arsenic pollution in surface water bodies. Sci Total Environ 442:247-254

52. Malakoff D (1998) Death by suffocation in the Gulf of Mexico

53. Mandal S, Choudhury BU, Satpati L (2020) Soil site suitability analysis using geo-statistical and visualization techniques for selected winter crops in Sagar Island, India. Appl Geogr 122:102249

54. Mandal S, Maji B, Sarangi SK, Mahanta KK, Mandal UK, Burman D, Digar S, Mainuddin M, Sharma PC (2020) Economics of cropping system intensification for small-holder farmers in coastal saltaffected areas in West Bengal: options, challenges and determinants. Decision, pp 1-15 
55. Mather K (1955) The genetical basis of heterosis. Proc R Soc Lond Ser B Biol Sci 144(915):143-150

56. Mazumder DNG, Ghosh A, Majumdar KK, Ghosh N, Saha C, Mazumder RNG (2010) Arsenic contamination of ground water and its health impact on population of district of Nadia, West Bengal, India. Indian J Community Med 35(2):331

57. Mazumder DNG, Haque R, Ghosh N, De BK, Santra A, Chakraborty D, Smith AH (1998) Arsenic levels in drinking water and the prevalence of skin lesions in West Bengal, India. Int J Epidemiol 27(5):871-877

58. Mirza MMQ (ed) (2006) The Ganges water diversion: environmental effects and implications, vol 49. Springer, Berlin

59. Mitra A (2020) Mangroves: a nutrient retention box. In: Mangrove forests in India. Springer, Cham, pp 87-114

60. Murphy K, Lammer D, Lyon S, Carter B, Jones SS (2005) Breeding for organic and low-input farming systems: an evolutionaryparticipatory breeding method for inbred cereal grains. Renew Agric Food Syst 20(1):48-55

61. Nelson ARLE, Ravichandran K, Antony U (2019) The impact of the Green Revolution on indigenous crops of India. J Ethnic Foods $6(1): 8$

62. Norra S, Berner ZA, Agarwala P, Wagner F, Chandrasekharam D, Stüben D (2005) Impact of irrigation with As rich groundwater on soil and crops: a geochemical case study in West Bengal Delta Plain, India. Appl Geochem 20(10):1890-1906

63. Norton GJ, Islam MR, Deacon CM, Zhao FJ, Stroud JL, McGrath SP, Islam S, Jahiruddin M, Feldmann J, Price AH, Meharg AA (2009) Identification of low inorganic and total grain arsenic rice cultivars from Bangladesh. Environ Sci Technol 43(15):6070-6075

64. Pani DR, Sarangi SK, Subudhi HN, Misra RC, Bhandari DC (2013) Exploration, evaluation and conservation of salt tolerant rice genetic resources from Sundarbans region of West Bengal. J Indian Soc Coastal Agric Res 30:45-53

65. Rahman MM, Mandal BK, Chowdhury TR, Sengupta MK, Chowdhury UK, Lodh D, Chanda CR, Basu GK, Mukherjee SC, Saha KC, Chakraborti D (2003) Arsenic groundwater contamination and sufferings of people in North 24-Parganas, one of the nine arsenic affected districts of West Bengal, India. J Environ Sci Health Part A 38(1):25-59

66. Rani NS, Satyanarayana ANV, Bhaskaran PK, Rice L, Kantamaneni $\mathrm{K}$ (2020) Assessment of groundwater vulnerability using integrated remote sensing and GIS techniques for the West Bengal coast India. J Contam Hydrol 238:103760

67. Ray R, Rixen T, Baum A, Malik A, Gleixner G, Jana TK (2015) Distribution, sources and biogeochemistry of organic matter in a mangrove dominated estuarine system (Indian Sundarbans) during the pre-monsoon. Estuar Coast Shelf Sci 167:404-413

68. Robertson DM, Saad DA, Schwarz GE (2014) Spatial variability in nutrient transport by HUC 8, state, and Subbasin based on Mississippi/Atchafalaya river basin SPARROW models. JAWRA J Am Water Resour Assoc 50(4):988-1009

69. Roychowdhury T, Tokunaga H, Ando M (2003) Survey of arsenic and other heavy metals in food composites and drinking water and estimation of dietary intake by the villagers from an arsenic-affected area of West Bengal, India. Sci Total Environ 308(1-3):15-35

70. Sahana M, Rehman S, Ahmed R, Sajjad H (2020) Analyzing climate variability and its effects in Sundarban Biosphere Reserve, India: reaffirmation from local communities. Environ Dev Sustain $1-28$

71. Samal AC, Kar S, Bhattacharya P, Santra SC (2011) Human exposure to arsenic through foodstuffs cultivated using arsenic contaminated groundwater in areas of West Bengal, India. J Environ Sci Health Part A 46(11):1259-1265

72. Sarangi SK, Islam MR (2019) Advances in agronomic and related management options for Sundarbans. In: The Sundarbans: a disaster-prone eco-region. Springer, Cham, pp 225-260

73. Sarkar SK, Bhattacharya BD (2010) Water quality analysis of the coastal regions of Sundarban mangrove wetland, India using multivariate statistical techniques. Environ Manag 24:159-172

74. Sarkar S, Ghosh A, Brahmachari K, Ray K, Nanda MK, Sarkar $D(2020)$ Weather relation of rice-grass pea crop sequence in Indian Sundarbans. J Agrometeorol 22(2):148-157

75. Shin H, Shin HS, Dewbre GR, Harrison MJ (2004) Phosphate transport in Arabidopsis: Pht 1; 1 and Pht $1 ; 4$ play a major role in phosphate acquisition from both low-and high-phosphate environments. Plant J 39(4):629-642

76. Signes-Pastor AJ, Mitra K, Sarkhel S, Hobbes M, Burló F, De Groot WT, Carbonell-Barrachina AA (2008) Arsenic speciation in food and estimation of the dietary intake of inorganic arsenic in a rural village of West Bengal, India. J Agric Food Chem 56(20):9469-9474

77. Suneson CA (1956) An Evolutionary Plant Breeding Method 1. Agron J 48(4):188-191

78. Suneson CA, Stevens H (1953) Studies with bulked hybrid populations of barley (no. 1488-2016-123899)

79. Dasgupta S, Ghosh S, Wheeler D (2020) Drinking water salinity in the Indian Sundarbans, The World Bank. http://www.sunda rbansonline.org/wp-content/uploads/2020/03/Note-DrinkingWater-Salinity-in-Indian-Sundarban.pdf

80. Tóth G, Hermann T, da Silva MR, Montanarella L (2018) Monitoring soil for sustainable development and land degradation neutrality. Environ Monit Assess 190(2):57

81. Upadhyay MK, Majumdar A, Barla A, Bose S, Srivastava S (2019) An assessment of arsenic hazard in groundwater-soil-rice system in two villages of Nadia district, West Bengal, India. Environ Geochem Health 41(6):2381-2395

82. USEPA (U.S. Environmental Protection Agency) Science Advisory Board (2008) Hypoxia in the Northern Gulf of Mexico

83. Wallace IS, Choi WG, Roberts DM (2006) The structure, function and regulation of the nodulin 26-like intrinsic protein family of plant aquaglyceroporins. BiochimicaetBiophysicaActa 1758(8):1165-1175

84. Wang P, Zhang W, Mao C, Xu G, Zhao FJ (2016) The role of OsPT8 in arsenate uptake and varietal difference in arsenate tolerance in rice. J Exp Bot 67(21):6051-6059

85. World Health Organization (2003) Arsenic in drinking-water: background document for development of WHO guidelines for drinking-water quality (no. WHO/SDE/WSH/03.04/75). World Health Organization

86. Xu XY, McGrath SP, Meharg AA, Zhao FJ (2008) Growing rice aerobically markedly decreases arsenic accumulation. Environ Sci Technol 42(15):5574-5579

87. Zhao FJ, Ago Y, Mitani N, Li RY, Su YH, Yamaji N et al (2010) The role of the rice aquaporin Lsi1 in arsenite efflux from roots. New Phytol 186(2):392-399

88. Zhao FJ, Ma JF, Meharg AA, McGrath SP (2009) Arsenic uptake and metabolism in plants. New Phytol 181(4):777-794

Publisher's Note Springer Nature remains neutral with regard to jurisdictional claims in published maps and institutional affiliations. 